\title{
What's New in Diabetes: Incretins and C-Peptide
}

\author{
Vincent Marks \\ Postgraduate Medical School, University of Surrey, Guildford, UK
}

Effective drug treatment of diabetes has changed dramatically since it first became available with the introduction of insulin in 1921. Today the list of drugs available or in development extends over several pages [1]. It includes insulin secretagogues (such as the sulphonylureas and meglitinides), insulin sensitisers, DPP4 inhibitors and the biguanide, metformin - currently the firstline treatment for type 2 diabetes - that are already well established, whilst others are in various stages of development [1].

The emphasis in treatment has also changed from alleviation of symptoms and prevention of death from diabetic keto-acidosis to avoidance of complications, most notably retinal, kidney and peripheral neural disease, due at least in part to microvascular involvement and myocardial ischaemia due to accelerated macrovascular disease.

In this brief review I intend to concentrate on aspects of advances in diabetes made possible by knowledge of the control of endogenous insulin secretion by enteric incretins and the role of C-peptide deficiency in the pathogenesis of the vascular complications of diabetes.

Differentiation of diabetes mellitus into insulin-dependent and non-insulin-dependent varieties, made initially on clinical grounds and confirmed by measurements of endogenous plasma insulin, has been replaced by an equally unsatisfactory classification into types 1 (c) 2011 S. Karger AG, Basel

1011-7571/11/0202-0101\$38.00/0

Fax +4161306 1234

E-Mail karger@karger.ch

www.karger.com
Accessible online at: www.karger.com/mpp and 2 which are united only by the fact that both are associated with reduced or absent insulin activity, hyperglycaemia and vascular disease.

The concept of diabetes as a bi-hormonal syndrome involving both insulin and glucagon is $>45$ years old [2]: the possibility that it is a tri-hormonal one is much newer [3]. Patients with type 1 diabetes suffer from insulin secretion and C-peptide deficiency from the onset of their disease. Those with type 2 diabetes do so only later in the course of their illness but may secrete excessive amounts of proinsulin from long before their illness becomes manifest.

Interest in gastrointestinal incretins in the pathogenesis and possible treatment of diabetes [4] has been revived with the introduction of GLP-1 therapy for type 2 diabetes [1]. GIP, the other major incretin whose main function appears to be control of fat metabolism, emerges as important in the pathogenesis of obesity and raises the possibility of treatment with GIP antagonists [5].

GLP-1 and its synthetic analogues have proved every bit as good as sulphonylureas at controlling blood glucose levels in patients with type 2 diabetes. They have the added advantages that unlike sulphonylureas, which stimulate secretion from preformed B-granules regardless of blood glucose levels, they do so only in the presence of hyperglycaemia and consequently do not produce fasting hypoglycaemia - the most feared complication of dia- 
betes treatment. Moreover, unlike sulphonylureas, they promote the synthesis of endogenous insulin, increase the number and prolong the life of pancreatic B-cells and are associated with weight loss rather than weight gain. Acute pancreatitis, their most serious side effect, is sufficiently rare to make their use a justifiable risk early rather than later in the illness as is currently advocated. Rouxen-Y bariatric surgery, which 'cures' type 2 diabetes by increasing GIP and GLP-1 release [6], carries too high a risk to justify its use except for morbid obesity.

C-peptide is the neglected hormone of diabetes due largely to the misplaced belief that it has no biological activity and serves only as a prop in the biosynthesis of insulin $[3,7]$. Its actions are unquestionably subtler than those of insulin but include control of endothelial function $[3,7,8]$ and its deficiency almost certainly plays an important role in the pathogenesis of diabetic retinopathy, nephropathy and neuropathy.

The addition of C-peptide to insulin given for diabetic therapy has long been advocated by the scientific com- munity but received little pharmaceutical support. Small, short-term trials of adding C-peptide to insulin therapy have been encouraging [9] but until larger, randomised trials are undertaken the jury is out. Nevertheless it is prudent to try to preserve endogenous insulin secretion for as long as possible, and this is more likely to be achieved by use of incretins and/or DPP4 inhibitors than other insulin secretagogues.

Whilst C-peptide undoubtedly plays a role in the pathogenesis of the microvascular complications of diabetes, pro-insulin and its partially cleaved products which are produced in supra-normal amounts in patients with type 2 diabetes - may contribute to the pathogenesis of its macrovascular complications [10]. This provides a rationale for the early introduction of exogenous insulin therapy - when other measures for restoring normo-glycaemia have failed - in order to reduce pro-insulin secretion and the glucotoxic effects of hyperglycaemia which include conversion from biologically active to biologically inert, glycosylated insulin, within the B-cell [11].

\section{References}

$>1$ Aicher TD, Boyd SA, NcVean M, Celeste A: Novel therapies and targets for the treatment of diabetes. Expert Rev Clin Pharmacol 2010; 3:209-229.

$>2$ Unger RH, Orci L: The essential role of glucagon in the pathogenesis of diabetes mellitus. Lancet 1975;305:14-16.

3 Marks V: C-peptide; in Wiley Encyclopedia of Molecular Medicine, 5 vol set. Hoboken, Wiley, 2002, pp 926-929.

$\checkmark 4$ Marks V, Samols E: Intestinal factors in the regulation of insulin secretion. Adv Metab Disord 1970;4:1-38.

$>5$ McClean PL, Irwin N, Hunter K, Gault VA, Flatt PR: (Pro3)GIP[mPEG]: Novel, longacting, mPEGylated antagonist of gastric inhibitory polypeptide for obesity-diabetes (diabesity) therapy. Br J Pharmacol 2008;155: 690-701.
-6 Knop FK: Resolution of type 2 diabetes following gastric bypass surgery; involvement of gut-derived glucagon and glucagonotropic signalling. Diabetologia 2009; 52:2270-2276.

$>7$ Wahren J, Ekberg K, Jornvall H: C-peptide is a bioactive peptide. Diabetologia 2007;50: 503-509.

8 Mughal RS, Scragg JL, Lister P, Warburton P, Riches K, O’Regan DJ, Ball SG, Turner NA, Porter KE: Cellular mechanisms by which proinsulin C-peptide prevents insulin-induced neointima formation in human saphenous vein. Diabetologia 2010;53:17611771 .
-9 Ekber K, Brismark T, Johansson B-L, Lindstrom P, Juntti-Berggre l, Norbby A, Berne C, Arnqvist HJ, Bolinder J, Wahren J: C-peptide replacement therapy and sensory nerve function in type 1 diabetic neuropathy. Diabetes Care 2007;30:71-76.

10 Yudkin JS, May M, Elwood P, Yarnell JWG, Greenwood R, Davey-Smith G: Concentrations of proinsulin-like molecules predict coronary heart disease risk independently of insulin; prospective data from the Caerphilly Study. Diabetologia 2002:45:327-336.

11 Lindsay JR, McKillop AM, Mooney MH, O'Harte FP, Bell PM, Flatt PR: Demonstration of increased concentrations of circulating glycated insulin in human type 2 diabetes using a novel and specific radioimmunoassay. Diabetologia 2003;46:475-478. 